\title{
UM DEBATE DISPERSO violência e crime no Brasil da redemocratização
}

Alba Zaluar

Professora de Antropologia do Instituto de Medicina Social da Uerj. Autora de Condomínio do diabo $e$ Cem anos de favela, entre outros

$\mathrm{U}$ $\mathrm{m}$ leitor familiarizado com a literatura internacional a respeito do tema logo percebe que a discussão acerca de "criminalidade e violência", no Brasil, tomou um rumo muito marcado pela recente história política do país e o papel que nela tiveram os intelectuais que trabalhavam nas universidades e organizações não-governamentais. Torna-se importante, pois, levar em conta a relação entre o campo intelectual e o campo político para entendermos os debates e afirmações reiteradas que ocuparam o pensamento dos que se dedicaram ao assunto. Os últimos 25 anos cobrem um período da história do país marcado por profundas mudanças políticas, sociais e econômicas, das quais os cientistas sociais participaram como pesquisadores e como cidadãos. Eles viviam tais mudanças e sobre elas pensavam dos lugares que ocupavam em suas instituições universitárias, partidos políticos e movimentos sociais, os quais sofreram várias inflexões. Mais recentemente, transformações na articulação entre os dois campos - o intelectual e o político -, com o advento das organizações não-governamentais, tiveram profundo impacto sobre as pesquisas e a literatura produzidas.

O debate começa na própria postura do cientista social enquanto um intelectual: se orgânico (A. Gramsci) ou específico (M. Foucault) - quando ligado ao movimento sindical ou alguma outra organização de classe -, se universal - quando exerce sua atividade referido a uma idéia universal e abstrata de justiça. Aquele primeiro tipo de intelectual usaria o seu saber nas "lutas reais, materiais e cotidianas"; estes seriam "portadores de universalidades" inscritas nesses direitos (Almeida, 1990). A alternativa vem revelar curiosos paradoxos, especialmente no caso dos que passam a militar pelos direitos humanos. Os últimos, a partir da década de 80 , embora baseados na teoria universalista e abstrata de tais direitos - na sua concepção natural e cristã -, apresentaram-se ao mesmo tempo como os aliados específicos das camadas mais atingidas pelo aparato policial e judicial do Estado. Não haviam abandonado de todo o modelo marxista dicotômico de sociedade, que opunha classe oprimida ao Estado, ou o conflito entre duas classes sociais antagônicas, mas militavam em defesa da cidadania no modelo da construção da nação, na qual deveriam ser incluídos os pobres do campo e das cidades. O paradoxo era maior no contexto urbano, onde os pobres figuraram simultaneamente como protagonistas principais dos crimes violentos cometidos e como vítimas preferenciais deles. Da dupla inserção dos pobres nas manifestações de violência, principalmente urbana, decorreram, então, dilemas éticos e políticos lancinantes e algumas ambigüidades teóricas. Outros modelos societários, nem sempre integrados aos demais, foram também acionados: o modelo da organização da sociedade civil, claro entre os que falavam da civilidade ou de um espaço civil (Paoli, 1982), de espaço público (Zaluar, 1991 a; b; c e 1994b), ou ainda as parcerias entre organizações não-governamentais, empresas, movimentos sociais e governos (Fernandes e Carneiro, 1996; CPDOC FGV/Iser, 1997 a e b); o modelo da sociabilidade violenta, que considera a violência como cerne do social ou legitimada na sociedade mais ampla (Machado da Silva, 1994; Misse, 1995b; Diógenes, 1998; Rifiotis, 1997. Muniz et alii, 1997 e 1998). 
Todavia, houve os que contornaram melhor os dilemas e resolveram algumas ambigüidades teóricas. Entre estes, os que incorporaram a teoria dos direitos humanos e civis a uma crítica da redução dos conflitos à "contradição principal" entre a classe dominante e a dominada, recusando-se igualmente à alternativa entre direitos universais e direitos históricos. Como afirmou C. Lefort na introdução ao livro de L. Oliveira (1995), os direitos humanos e civis deixariam, neste caso, de ser concebidos como mera superestrutura do individualismo burguês e passariam a ser fundamento das relações sociais e instituições numa sociedade democrática. Na nova cultura política que se forma, "a defesa das liberdades individuais e civis desemboca na concepção de uma sociedade plural, atravessada por múltiplas linhas de clivagem entre dominantes e dominados, de forma que a luta contra as desigualdades não se resume mais a uma luta pela transformação das relações de propriedade" (Lefort, apud Oliveira, 1995). Os múltiplos conflitos envolvendo relações de gênero, geração, estilos e etos, inclusive no interior da mesma classe social, tornaram os modelos de sociedade mais complexos.

Ademais, a competição entre os cientistas sociais e a delimitação das fronteiras entre as disciplinas das ciências sociais, sempre tão problemáticas pelo seu estoque comum de teorias e pais fundadores, também são importantes vetores para entender o debate. Essa disputa esteve particularmente clara entre os que sublinharam a importância dos indicadores sociais ou estatísticas oficiais sobre os crimes na formulação de uma política pública dissuasória e aqueles que, baseados em material qualitativo, chamavam a atenção para as práticas cotidianas dos policiais, bem como para as condições de vida existentes seja nas áreas onde viviam os candidatos à delinqüência, seja nas prisões. Neste artigo, vamos tratar apenas em breves pinceladas a sociologia dos dois campos e dedicar-nos mais ao mapeamento do debate, às divergências e convergências entre cientistas políticos, sociólogos e antropólogos que estudam o tema, enquanto representantes de perspectivas ou abordagens distintas dos mesmos objetos empíricos: a violência e a criminalidade, que viraram rapidamente dos mais candentes problemas urbanos no período, tal como mensurado em inúmeras pesquisas de opinião.

Na avaliação da produção acadêmica do período, baseamo-nos no extenso material de que dispunhamos pessoalmente (dispomos de uma coleção de trabalhos sobre o tema), assim como dos arquivos do Urbandata, do Iuperj, no Rio de Janeiro, nos quais o tema foi pesquisado. ${ }^{1}$ Desta pesquisa resultou um levantamento bastante abrangente, mas ainda incompleto, dos artigos, livros e capítulos de livros publicados a respeito, o que permitiu fazer uma contagem dos principais subtemas sobre os quais versavam, mesmo que não fossem o seu foco principal. Algumas surpresas nos aguardavam. Junto à hegemonia indiscutível do paradigma marxista ou da criminologia crítica, a questão institucional predominou de longe sobre uma perspectiva sociológica que focaliza a sociedade na sua autonomia, o que nos faz concluir que os trabalhos de cientistas políticos, "polito-sociólogos" e "polito-antropólogos" tiveram grande importância nos últimos 28 anos. Isto nada mais é do que outra maneira de afirmar a relevância política que o tema adquiriu a partir do final da década de 70.

Um dos autores no debate oferece uma explicação para esta surpresa: é que o paradigma marxista, que influenciou muito os cientistas sociais brasileiros, mostrou-se particularmente fecundo e inovador justamente na crítica feita aos "crimes do capital e aos dispositivos de violência do Estado" (Misse, 1997), abundantes no período militar e durante a limitada e incompleta redemocratização. Além disso, desde o final dos anos 70 , a influência da obra de Foucault sobre os cientistas sociais brasileiros teria deslocado o enfoque para os "dispositivos que o poder tem de produzir a verdade criminal e discipliná-la”. É a partir daí que faz a crítica às teorias sociológicas canônicas ainda "enfocadas na causalidade" e "envolvidas no próprio objeto" (ibidem). A combinação Marx/ Foucault pode ter germinado alguns híbridos estranhos aos olhos dos que repelem o ecletismo teórico, mas teve, sem dúvida, eficácia explicativa naqueles mecanismos do poder estatal e poder disciplinar mais evidentes: a polícia e a prisão (Adorno, 1990, 1991b e c; Carrara, 1991 a; b; Kant de Lima, 1989 e 1997; Misse e Motta, 1979).

No decorrer dos anos seguintes, essa hegemonia mostrou suas inúmeras brechas e outros modelos foram acionados para a interpretação da questão. Alguns recusaram as teorias que consideram anti-racionais por valorizar a Diferença e o Contra-poder como alternativas para a sociedade burocratizada, esta confundida com o racionalismo e a modernidade. Várias versões contemporâneas do liberalismo, ${ }^{2}$ após o fracasso do socialismo real e as crises simultâneas do marxismo e do iluminismo, também inspiraram diversos autores. Era a construção da nação e da cidadania ou o processo de democratização que os preocupava. Foram eles principalmente que discutiram os de- 
safios que a violência urbana ou difusa impunha ao processo de democratização do país, ainda num enfoque político da questão. Esse processo foi entendido mais no sentido institucional e político do que societário e técnico, concentrando-se, sobretudo ultimamente, no debate sobre as formas de controle democrático da criminalidade (Adorno, passim; Bretas, 1997; Caldeira, 1995 e 1997; Cavalcante, 1985; Fischer, 1985; Paixão, 1988 e 1995; Pinheiro, passim; Velho, 1980; Zaluar, 1991a e c; 1994b).

Foram eles também que, no plano societário, estudaram os percalços do processo civilizatório, entendido como a democratização da sociabilidade e a criação de um "espaço civil" ou "público" para a negociação de conflitos num quadro de crise urbana. Aqui a dissensão é grande. Os estudos sobre o medo e o apoio dado pela sociedade a políticas despóticas ou extremamente repressivas devido à crise, conduzem autores a qualificar a sociedade brasileira como o antônimo da cordialidade e cooperação: a inversão da teoria do homem cordial brasileiro. Os que tratam da transformação psicológica e social que retira a sensibilidade contra as práticas violentas, nas quais predominam o prazer de infligir dor física e moral ao vencido e destruí-lo na liberdade irrestrita da luta privada, também divergem. Alguns fazem diagnósticos sobre o caráter da sociedade brasileira em uma perspectiva culturalista (violenta ou despótica), outros sobre processos específicos que estariam ocorrendo em certos setores da população, apesar dos antídotos (Benevides, 1981, 1982, 1983; Cardia, 1997; Caldeira, 1992; CDDHBR, 1994; Cecchetto, 1997 a e b; Fernandes, H., 1992; Machado da Silva, 1994; Paoli, 1982; Soares et alii, 1996; Velho, 1987 e 1996; Sussekind, 1987; Vargas, 1993; Zaluar; 1985, 1988, 1989, $1994 b$ e 1998 a e b).

A preferência, na explicação sociológica, para o modelo dicotômico que divide a sociedade em duas categorias antagônicas, ainda que empregando diferentes conceitos - tais como dominação, exploração capitalista, segregação racial ou exclusão - atesta a continuidade do dualismo no pensamento social brasileiro e marca os textos produzidos no período da abertura e da redemocratização (Guimarães, 1982; Carvalho, 1985, 1994 e 1995; Oliven, 1980, 1981 e 1982; Kowarick e Ant, 1981; Machado e Tapparelli, 1993; Misse e Motta, 1979; Zaluar, 1983 e 1986b). A apresentação das cidades inexoravelmente divididas em duas partes muitas vezes levou os pesquisadores a repetir canonicamente argumentos recémaparecidos no debate internacional, mas já anteriormente criticados entre nós, como o da teoria da marginalidade travestida de "exclusão".

Apesar disso, a discussão sobre uma ordem pública democrática, sobre os problemas na concretização da cidadania no Brasil, sobre o direito à vida e à segurança de toda a população, inclusive a pobre, exatamente por desnudar os obstáculos de tal modelo, tornou mais ricas as abordagens apresentadas nos últimos anos. As funções, organização e práticas cotidianas da polícia e do sistema penal, em contraste com o sistema normativo ou legal, tiveram de ser reavaliadas com menos dogmatismo teórico, o que não quer dizer que se tenha chegado a um consenso. Longe disso, o debate continua aceso.

Desde os anos 80, deu-se a primeira dicotomia entre os que estudaram e escreveram sobre o tema, que persiste sob nova terminologia até hoje. Os que denunciavam a miséria, a perda do poder de compra do salário, a exploração, a ausência de investimentos na educação e na saúde para o aumento da violência, que já começava a preocupar o governo federal, postavam-se na esquerda do espectro político ou no que foi durante muitos anos chamado de "a esquerda penal", enquanto os que insistiam em analisar a questão institucional, inclusive as práticas policiais de violência contra os pobres e a eficiência da polícia em proteger a vida e a propriedade do cidadão, em termos de política pública para todos, eram considerados "de direita". Os que desde logo tomaram a criminalidade como objeto digno da atenção de cientistas sociais permaneceram até certo ponto estigmatizados como conservadores e empiristas até quase o fim dos anos 80 . Mas partiu deles grande parte do entendimento que hoje se tem a respeito dos mecanismos perversos, círculos viciosos e obstáculos institucionais rotineiros que alimentam as carreiras criminosas de jovens pobres, bem como dos policiais envolvidos nas práticas ilegais do extermínio, da extorsão, do seqüestro, da corrupção e da repetida violação dos direitos humanos ou civis dos cidadãos brasileiros.

Os dilemas morais e ideológicos que atormentavam os pesquisadores na época poderiam ser resumidos nas afirmações inequívocas de L. Oliveira (1995a) sobre o paradigma teórico então hegemônico. Ao contrário da visão da polícia apenas como aparelho repressivo da classe dominante e, pois, do Estado, propunha uma visão mais complexa, "capaz de compreender e explicar os casos pesquisados no interior das classes populares que solicitaram a ação dos policiais em diversas ocasiões". Além dele, todos os que denunciavam a polícia de dupla face uma condescendente com os ricos e a outra arbitrária e 
violenta com os pobres - não deixavam de admitir a função da polícia como prestadora de serviços à população pobre, nem a necessidade de uma polícia orientada pelos critérios universais da cidadania e mais eficiente no combate aos crimes que também atormentavam os destituídos (Adorno, 1992 e 1995; Benevides, 1981 e 1983; Bretas, 1997; Caldeira, 1992; Campos, 1978 a e b e 1980; Kant de Lima, 1995, Paixão, 1982 e 1988; Paixão e Beato, 1997; Zaluar, 1983, 1985a, 1986b, 1991b).

$\mathrm{Na}$ perspectiva antropológica, a contenda não esteve menos acirrada. $\mathrm{O}$ relativismo cultural, sua marca disciplinar, teve o seu uso repleto de armadilhas, devido aos paradoxos, tensões e dilemas teóricos e éticos contidos no próprio objeto. Um atento pesquisador, ao lidar com seu material etnográfico recolhido junto aos protagonistas da violência e do crime, deveria discutir afinal de que relativismo se tratava: se cultural, se epistemológico ou moral; se controlado ou restrito, se radical. ${ }^{3}$ Em alguns textos, no entanto, a preocupação excessiva com os limites reconhecíveis, as identidades claras e as lógicas fechadas serviu para afirmar diferenças, mas, de quebra, reificou-as e essencializou-as, o que criou problemas sérios à análise das ditas "subculturas" criminais. Primeiro, porque a dicotomização de mundos - o dominante ou o marginal; o incluído e o excluído - acabou fazendo surgir aquilo que Habermas chamou de metafísica negativa, na qual o mundo do desviante, marginal ou divergente, foi apresentado como a alternativa ao mundo oficial e como tal justificado. As formas do distinto, no caso, apelaram para uma esteticização da violência, que chegou a ser apresentada como saída para a dominação, a exploração, a exclusão dos dominados, explorados e excluídos, ${ }^{4}$ ou, mais simplesmente, como uma estratégia de sobrevivência deles (Oliven, 1980 e 1982), mesmo quando seu caráter fugidio e intermitente era acentuado (Diógenes, 1998; Rafael, 1998; Rifiotis, 1997). Segundo, porque o foco nas fronteiras e identidades impediu o entendimento das pontes e passagens múltiplas, trocas contínuas e redes entrecortadas que articulam diferentes mundos, grupos ou culturas em processos históricos intermináveis e cambiantes. Esses problemas teóricos são especialmente claros no contexto urbano, em que dificilmente se encontram o isolamento e a completa autonomia de um grupo, assim como no contexto de um planeta em processo de globalização, na qual a comunicação é cada vez mais rápida e generalizada, além de desterritorializada. Tais dilemas marcaram as próprias concepções de violência adotadas pelos autores.

\section{O LEVANTAMENTO DO TEMA}

No balanço da produção acadêmica dos cientistas sociais brasileiros, ${ }^{5}$ encontramos os seguintes subtemas: sobre a polícia ou vinculando a organização e a função desta instituição no Estado e na sociedade, 61 trabalhos; sobre o sistema penal, 19; sobre o funcionamento da Justiça, 24, sem contar os oito trabalhos que discutiam formas alternativas, preventivas ou democráticas de lidar com a questão do crime e os seis que denunciavam a privatização dos meios de garantir a segurança da população urbana. Isto perfaz um total de 118 trabalhos debatendo as instituições brasileiras encarregadas de combater o crime e manter a ordem pública ou, como afirmam muitos dos cientistas, a ordem social vigente com ela confundida. Entre estes, a polícia, inicialmente objeto antes de denúncias indignadas do que de estudos específicos sobre as suas organizações e práticas cotidianas, foi focalizada em mais da metade de todos esses estudos.

Os textos que tomaram a perspectiva estrutural na explicação para os fenômenos da violência, seja pela via da estrutura social ou urbana desigual e iníqua, seja pela via da luta de classes, seja pela via da exclusão ou da segregação das favelas, somaram 40. Os que abordaram o tema por meio de interpretações das representações sociais, do imaginário ou do senso-comum, apontando sua importância para entender o medo, os preconceitos sociais contra determinados setores da população e o apoio da população amedrontada e manipulada pela mídia a políticas repressivas e imediatistas, também totalizaram 40 . Os que vincularam a violência às dificuldades de agregação e de organização da sociedade civil ou ainda à atomização crescente, um modo de falar do enfraquecimento dos movimentos sociais tão em voga na década de 70 , não passaram dos 11. Nesses subtemas predominaram os estudos feitos na perspectiva dita qualitativa, o que não significa dizer nem perspectiva antropológica nem pesquisa de campo etnográfica, embora alguns as tenham. Cientistas sociais com formação em sociologia e antropologia escreveram a maioria desses estudos, cujo total foi de 81, nos quais os estudos etnográficos em profundidade, que conseguiram fazer entender o etos ou as práticas sociais ou ainda a subcultura dos grupos estudados, permaneceram raros nos primeiros 20 anos (Ramalho, 1979; Zaluar, 1985, 1988 e 1989). Isso não é de se espantar pelas dificuldades enfrentadas no campo e no relacionamento com o "objeto/sujeito" do estudo. Além das penosas barreiras para conquistar a confiança dos que vivem na ilegalida- 
de, na marginalidade ou na clandestinidade, a defender seus segredos e identidades de todos os que os ameaçam, existe o risco de vida que se corre em locais onde os tiros fazem parte dos ruídos de fundo e as balas perdidas (e seus efeitos mortais), do cenário local (Zaluar, 1995). Nos últimos anos, entretanto, muitas etnografias surgiram, a maior parte delas situada em favelas no Rio de Janeiro (Alvito, 1996 e 1998; Cecchetto, 1997a; Cunha, 1996; Rafael, 1998), outra em Fortaleza (Diógenes, 1998) e algumas em São Paulo (Cardia, 1997; Gregori, 1997; Marques Jr., 1991; Mingardi, 1998; Vargas,1993). Várias etnografias foram também feitas em delegacias policiais, seguindo o estudo pioneiro de Paixão (1982), a saber: Mingardi (1992), Mota (1995), Muniz (1996) e Muniz et alii (1997), Vargas, J.D. (1997) e um estudo de história social que reconstituiu as experiências diárias dos policiais para explicar a dupla face de sua atuação hoje (Bretas, 1997).

Finalmente, os estudos que denunciaram a vitimização de certos setores da população divididos por idade, gênero ou cor (51) sobrepujaram os estudos que exibiam ou discutiam o aumento dos índices de criminalidade (33). Os primeiros contaram as vítimas, no duplo sentido da palavra, fossem eles pesquisas amostrais com dados de primeira mão feitas em algumas capitais brasileiras (quatro), fossem pesquisas baseadas nos dados de mortalidade violenta do Sistema de Informações sobre a Mortalidade (SIM), do Ministério da Saúde (seis), fossem eles pesquisas de âmbito mais restrito sobre violência contra mulher (14), violência contra crianças e adolescentes (21), ou envolvendo a cor da vítima e do agressor (cinco). Os segundos contaram os crimes ou os criminosos com base em dados oficiais da Polícia ou em levantamentos feitos nos arquivos do Judiciário ou do Sistema Penal no Brasil, em números gerais para anos específicos (12), numa perspectiva histórica ou tomando uma série histórica de tais dados (oito), focalizando a idade (nove) ou o gênero (quatro) dos agressores. Tanto as primeiras quanto as segundas, nas quais os métodos ditos quantitativos predominaram, foram aprimorando suas técnicas para construir indicadores sociais ao longo dos últimos 20 anos, conquistando novos adeptos e, assim, experimentando uma certa hegemonia no campo durante os anos 80 e 90 .

Não é de se estranhar, portanto, que os trabalhos dedicados a entender as importantes transformações na organização social dos criminosos e nos novos tipos de crime tenham sido tão poucos, apenas 20, metade dos quais escritos pela autora $(1983,1988,1989,1993$ a e b,1994a e b, 1996), e os outros por pesquisadores de diversas insti- tuições acadêmicas do Rio de Janeiro: Campos Coelho (1987a e b); Caldeira (1995 e 1997); Chinelli e Machado da Silva (1993); Misse (1995a, 1995b, 1997); Alvito de Souza (1996 e 1998); Goldman (1990); Machado da Silva (1994); Shirley (1997) - todos eles abordando o crime dito organizado no Rio de Janeiro, com exceção dos estudos de Shirley numa favela em Porto Alegre e de Machado da Silva, que faz uma crítica teórica geral da associação entre crime organizado e crise institucional no Brasil. É preciso mencionar também os importantes trabalhos de Almeida e Barreira sobre o "crime do mando" nas áreas rurais. Barreira escreveu sobre as mudanças ocorridas neste crime no sertão nordestino. Se tradicionalmente envolviam o pistoleiro e o mandante, hoje os crimes por encomenda fazem entrar em cena os bandos de homens armados e treinados para atingir as lideranças comunitárias e expulsar moradores incômodos das propriedades rurais. Em São Paulo, os estudos sobre a organização do crime ficaram restritos inicialmente à figura do justiceiro e suas conexões com a polícia e a vizinhança (Fernandes, 1992) ou aos grupos de extermínio (Adorno e Cardia, 1997, Costa, 1998). Só mais recentemente, Mingardi (1997 e 1998) passou a discutir o crime organizado nas suas diversas manifestações neste Estado.

Em compensação, os estudos que exploraram principalmente as transformações urbanas, que vão constituir o cenário de crise, para explicar o aumento da criminalidade e a percepção da violência, predominaram em São Paulo. Para citar apenas alguns, os trabalhos de Kovarick et alii (1981), Brant (1989), Caldeira (1992), Vargas (1993), Cardia (1997) aprofundaram o conhecimento da crise urbana e dos conflitos decorrentes de mudanças diversas, inclusive as novas divisões espaciais - não apenas duas (favela/asfalto; Norte/Sul) - na cidade de São Paulo, ao interpretar o seu impacto sobre o medo e o crescimento da violência nesta cidade observados. No Rio, o foco nas transformações ou na estruturação urbana seguiu muito mais a fórmula dualista já mencionada (Carvalho, 1985, 1994 e 1995; Cunha, 1996; Minayo, 1990; Soares et alii, 1996; Souza, 1993). A exceção são os trabalhos de M.J.L. de Souza (1994 e 1996), que enfocam os efeitos perversos do tráfico de drogas sobre a dinâmica socioespacial no Rio de Janeiro, dentro e fora das favelas. Além do nosso, é claro.

Como o debate foi público e mais articulado a questões ideológicas e partidárias que acadêmicas, envolvendo conjuntamente jornalistas, militantes e cientistas sociais, também não é de se estranhar que apenas três 
resenhas bibliográficas críticas tenham sido encontradas, duas delas escritas por Adorno (1991a e 1993) e a outra, focalizando a questão da violência na área da saúde, por Minayo e Souza (1990).

\section{O TEMA E SUAS SUBDIVISÕES}

Ao longo dos últimos 25 anos, formam-se vários campos temáticos com questões metodológicas, teóricas e ideológicas distintas. Como o debate nunca foi bem organizado e bem fundamentado teoricamente, optamos não pelos modelos teóricos, quase sempre sobrepostos num mesmo autor, mas pelos temas que, mesmo que nem sempre centrais em cada período da história brasileira no período, estão sempre presentes na literatura, na medida em que combinam certos aspectos para lhes dar uma feição mais teórica. Resumindo-os, são eles: 1) a reflexão sobre o que é violência e os seus múltiplos planos e significados, dependendo do agente e da ótica adotada, o que redunda quase sempre em apontar os males a serem combatidos, tendo em vista a conotação negativa que a palavra carrega; 2) as imagens ou representações sociais do crime e da violência e o medo da população, muitas vezes apresentada como irracionalmente envenenada pela mídia que manipularia o seu sentimento de insegurança através do exagero ou excessiva exposição de notícias sobre crimes, ou emocionalmente reativas a uma situação não bem entendida de conflitos, tensões e problemas socioeconômicos acirrados. Daí resultou uma crítica cultural, denunciando a natureza violenta da sociedade brasileira e a sua falta de concepção de cidadania; 3) contar as vítimas e os crimes, ou seja contar, na dupla denotação do termo, os números e os sentidos da vitimização ou da criminalidade violenta, mais recentemente discriminada por gênero, idade ou cor; 4) a procura de explicações para o aumento da violência e da criminalidade, com um debate particularmente interessante e rico na questão da relação entre pobreza e violência, e, mais recentemente, do crime organizado; 5) o problema social da criminalidade como tema de política pública, que pode ser dividida em dois momentos - o primeiro é quando persiste o conflito entre os dois paradigmas de políticas de controle da criminalidade, um, que concebe o problema criminal como efeito de macropolíticas sociais, e outro, mais voltado para os custos da vitimização a curto prazo, que afirma a autonomia da política de segurança pública; e o segundo momento é quando se diferenciam e se opõem com mais clareza a militarização da segurança e seu controle democrático, reconhecendo a sua autonomia. Neste item, é claro, figura como central a questão da violência institucional entre as mazelas e profundos problemas das políticas públicas brasileiras, em particular da polícia. As calamidades do sistema penal brasileiro constituem parte importante da discussão. Este tema foi muito bem estudado na virada da década de 80 , quando se apontou para os absurdos da superlotação, da deterioração dos presídios e penitenciárias, da ineficiência do Judiciário que mantinha presos com penas já cumpridas ou fruto de erros judiciários. Hoje discutem-se sobretudo as medidas mais práticas de adoção de penas alternativas e mudanças no Código Penal, entre as quais a descriminalização de certos "crimes sem vítimas", como o uso e o comércio de substâncias psicoativas.

\section{QUE VIOLÊNCIA E O QUE É VIOLÊNCIA?}

A dificuldade na definição do que é violência e de que violência se fala é o termo ser polifônico desde a sua própria etimologia. Violência vem do latim violentia, que remete a vis (força, vigor, emprego de força física ou os recursos do corpo em exercer a sua força vital). ${ }^{6}$ Esta força torna-se violência quando ultrapassa um limite ou perturba acordos tácitos e regras que ordenam relações, adquirindo carga negativa ou maléfica. É, portanto, a percepção do limite e da perturbação (e do sofrimento que provoca) que vai caracterizar um ato como violento, percepção esta que varia cultural e historicamente. As sensibilidades mais ou menos aguçadas para o excesso no uso da força corporal ou de um instrumento de força, o conhecimento maior ou menor dos seus efeitos maléficos, seja em termos do sofrimento pessoal ou dos prejuízos à coletividade, dão o sentido e o foco para a ação violenta. Além de polifônica no significado, ela é também múltipla nas suas manifestações. Do mesmo modo, o mal a ela associado, que delimita o que há de ser combatido, tampouco tem definição unívoca e clara. Não é possível, portanto, de antemão, definir substantivamente a violência como positiva e boa, ou como destrutiva e má. Dessa definição relativizada (porém não relativista) da violência e do mal só escapam os substantivistas renitentes. A questão é saber se existiriam valores não contextualizados, direitos fundamentais, valores universais, o que obrigaria a pensar sobre a violência pelo lado dos limites que tais valores e direitos imporiam à liberdade individual ou coletiva (Adorno, 1993, Pinheiro, 1984; Zaluar, 1993b e 1994a). Nem mesmo os cientistas sociais escapam de tais 
dificuldades e dilemas, o que parece claro quando se buscam os vários sentidos e os múltiplos usos que o termo teve na produção acadêmica do período.

De início, a partir de 1970, os trabalhos que tocam no problema da violência muito raramente a tomam pelo ângulo da criminalidade, considerada como um "problema" a ser enfrentado. Não havia ainda a comoção pública e o destaque na mídia que o aumento da criminalidade provocou a partir da década de 80 , embora aqui e ali ${ }^{7}$ já tivessem começado a surgir as primeiras pesquisas sociológicas sobre crime, quebrando a exclusividade que juristas e psiquiatras tinham sobre o assunto no Brasil (Carrara, 1991a e b; Misse, 1995b). É só no final da década que o problema se torna também nacional e social, e não apenas jurídico e médico, quando é formada, por iniciativa do Ministério da Justiça, uma comissão de estudiosos, dos quais fazem parte vários cientistas sociais, que prepararam um relatório sobre o tema. ${ }^{8}$ A questão da criminalidade já estava, então, na pauta das grandes preocupações do governo federal.

Todavia, outros estudos predominaram na década de 70. Eram os movimentos sociais, nas suas várias modalidades urbanas e rurais, que concentravam a atenção daqueles que pensavam a respeito da violência partida do povo ou da sociedade. Por isso, a extensa bibliografia sobre movimentos messiânicos e cangaço no campo, assim como, entre os mais recentes, quebra-quebras urbanos e seus congêneres rurais, revela o que instigava a imaginação e a curiosidade dos cientistas sociais então. Dessa reflexão, que continua vivaz até 1984, é a violência "legítima contra o Estado ilegítimo e ilegal” (Paoli, 1982; Pinheiro, 1984; Oliven, 1981 e 1982) que está em causa. Conseqüentemente, embora comparadas ao modelo do movimento operário organizado estas manifestações não fossem concebidas como inteiramente modernas, haveria uma semente de cidadania nelas, na medida em que, por meio delas, a população destituída e oprimida afirmaria alguns de seus direitos básicos de cidadania enquanto moradores da cidade. Tais manifestações eram classificadas de pré-políticas por sua insistência nos métodos violentos e destrutivos, inclusive do equipamento urbano que servia a essa população, mas ao mesmo tempo a violência "popular" era entendida como reação legítima ao arbítrio, ou como efeito da desordem instaurada pelo poder ilegítimo do Estado e pelo capitalismo selvagem que nem conseguiam fornecer um bom sistema de transportes urbanos para os trabalhadores. No quadro urbano, entretanto, o inflado interesse nos estudos sobre movimentos ou as- sociações de moradores que não tratavam da violência tinham uma razão política forte, especialmente em cidades como o Rio de Janeiro, onde o movimento sindical havia sido severamente reprimido durante o regime militar. De fato, muitos dos militantes sindicais migraram de seus sindicatos para as associações de moradores de seus bairros, nas quais passaram a politizar as questões locais, vinculando-as ao que foi então denominado "a questão urbana" por Manuel Castel.

A violência advinda do poder ilegítimo do Estado, é claro, tomou ainda mais espaço nas preocupações dos cientistas sociais no período militar, mas persiste até hoje, visto que, com a exceção de Minas Gerais, entre 1991 e 1997, e, mais recentemente, do Rio Grande do Sul, as práticas desenvolvidas nas polícias pouco se alteraram no país. São inúmeros os trabalhos sobre a violência policial, a tortura, os esquadrões da morte e seus congêneres, os horrores da prisão (Adorno, 1990, 1991a e b; Benevides, 1985; Capeller, 1995; Kant de Lima, 1995; Oliveira, 1994; Oliven, 1980, 1981 e 1982; Pinheiro, 1982 e 1984; Ramalho, 1979; Zaverucha, 1994). Os objetos mais comuns na virada da década de 80 são justamente a brutalidade oficial, militar e estatal, e a para-estatal, clandestina e oficiosa das organizações paramilitares que continuaram a exercer o terror do Estado, termo comum na literatura até os dias de hoje, apesar dos enormes esforços, a partir da Constituição de $1988,{ }^{9}$ em estabelecer um estado democrático de direito no país. A continuidade com as práticas extralegais do período autoritário é tema recorrente em muitos trabalhos (Adorno e Cardia, 1997; Caldeira, 1991; Capeller, 1995; Costa, 1998; Fernandes, 1992; Oliveira, 1994; Pinheiro, 1984; Zaluar, 1994b). Costa (1998) reconstitui a história do esquadrão da morte, apontando a sua vinculação inicial com os órgãos da repressão do regime militar e a sua permanência no presente.

Fugiram à regra dos estudos no período aqui considerado os que enfocaram os linchamentos de suspeitos de crimes comuns, cometidos pela população dos bairros pobres e periferias das grandes cidades brasileiras e que começaram a ocorrer com frequiência à proporção que a nação reentrava no estado liberal de direito, sem contudo alcançá-lo plenamente (Benevides, 1981, 1982 e 1983; Caldeira, 1991). ${ }^{10}$ Esta manifestação da violência popular criou um grande mal-estar naquela antes clara e nítida separação entre a violência legítima dos movimentos populares e a ilegítima dos órgãos estatais e para-estatais. Primeiro, porque não se podia mais considerar esta reação popular "pré-política" como um indício inequívoco 
de retomada da cidadania. Segundo, porque obrigava a pensar e mencionar o aumento da criminalidade nos grandes centros urbanos, entendida por muitos cientistas sociais como uma preocupação "falsa", inflacionada pelo sensacionalismo da grande imprensa.

As convergências encontradas na interpretação dos linchamentos são, por isso, muito importantes para se compreender os compromissos políticos de seus autores. $\mathrm{O}$ conceito de justiça popular, acionado por todos, é primeiramente entendido simplesmente como "justiça feita com as próprias mãos" (Benevides, 1982), esta por sua vez compreendida como uma revolta coletiva contra o sistema de justiça - especialmente a polícia desinteressada nos crimes cometidos contra os populares - e contra os demais serviços públicos que não funcionariam. Os populares não seriam os verdadeiros culpados. J.S.Martins também aciona o descrédito da Justiça, mas acrescenta a demanda por participar na sua administração, definindo critérios de julgamento e executando a pena. Isso seria não uma reprodução de práticas policiais violentas, mas de concepções simbólicas a respeito da morte que a tomam como ritual de banimento do social e do humano. Para Sinhoretto, o linchamento, além de expressar o abismo entre a expectativa da população e o funcionamento do sistema de Justiça, seria uma resposta imediata a crimes graves, cometidos contra pessoas pertencentes a famílias que participam do julgamento, determinando o ritmo dele e executando o acusado com o apoio de amigos, parentes e vizinhos no bairro concebido como o locus da moralidade ameaçado pelo "bandido". Esses textos, portanto, focalizam a forma coletiva de revolta popular. Concentram-se mais em compreender as circunstâncias do ato e menos nas políticas públicas que iriam combater o linchamento entre os populares.

Os estudos sobre grupos de extermínio, que reconstituíram a passagem do sistema de repressão do regime militar para a privatização da segurança militarizada, não ficaram de todo livres do mal-estar e das ambivalências. Isto porque, como apontam Adorno e Cardia (1997), os grupos de extermínio têm atualmente composição dupla: policiais e moradores do local constituem os membros mais comuns de tais grupos, organizados para a execução sumária e sistemática de suspeitos de cometer crimes. Haveria, então, uma duplicidade dos vizinhos que fazem contratos com tais grupos ou aprovam sua ação como forma de compensar a ineficiência do sistema de Justiça, apelando para a solução extralegal e fatal (Adorno e Cardia, 1997).
Fora do padrão estavam também os estudos que focalizavam a violência dos crimes cometidos por pessoas pertencentes às classes sociais desfavorecidas, mesmo quando recusavam a associação pobreza/crime, da qual trataremos mais adiante. Tanto os estudos quantitativos que apontavam um inequívoco aumento da criminalidade, especialmente a violenta (a que mais atinge os pobres ou os populares) durante as décadas de 80 e 90 (Adorno, 1992; Beato et alii, 1997; Coelho, 1992; Paixão, 1983, 1990; Soares et alii, 1996, Zaluar, 1994b), quanto os raros estudos etnográficos que enfocavam grupos de traficantes e suas relações na vizinhança (Zaluar, 1983, 1985, 1988, 1989, 1993 a e b, 1994b, 1996; Shirley, 1997) não podiam deixar de mencionar este aumento e tentar entendê-lo com alguma plausibilidade. O quadro montado a partir desses dados sobre a vida entre os pobres estava longe de ser o de uma comunidade integrada, participante ou democrática. Haveria ali violências específicas ou males a combater, como, aliás, denunciaram os autores que se dedicaram a estudar os linchamentos e grupos de extermínio. Os direitos à vida e à propriedade, garantidos pela Constituição e desejados pela população, inclusive os pobres, estariam sendo lesados pelos predadores violentos, fossem eles policiais corruptos, traficantes ou simples ladrões e assaltantes, bem como pelos exterminadores, fossem eles policiais ou moradores.

De todo modo, desde os anos 70, o discurso predominante, mesmo entre alguns dos últimos textos, era de que os verdadeiros problemas e questões seriam evidentemente a miséria crescente, o desemprego, a falta de serviços públicos eficientes, em especial no setor da saúde e da educação, e a ausência de políticas sociais, todos entendidos como violência perpetrada pelo Estado contra a população necessitada (Kowarick e Ant, 1981; Oliven, 1980, 1981 e 1982; Sussekind, 1987). A indiferenciação entre essa "violência" e a outra, utilizada para denunciar os desmandos do poder militar abusivo e ilegítimo, não pareceu trazer grandes preocupações teóricas em torno do próprio conceito de violência utilizado. Tudo era violência. Deslizando da opressão física para a necessidade material, continuava-se a denunciar o Estado. Esta formulação aparece pela primeira vez com clareza no texto, de orientação solidarista cristã com fortes tons marxistas, do Pe. Fernando D'Avila, membro do grupo de trabalho que escreveu o relatório encomendado pelo Ministério da Justiça em 1980: "As primeiras formas de violência (que vem de cima para baixo) são as propiciadas pelas estruturas sociais iníquas... Quem define o ato violento? Os que 
detêm o poder. Como definem o ato violento? Como transgressão das regras criadas pelo mesmo poder. Assim, se entre essas regras existem regras violentas, não são caracterizados como atos violentos, por exemplo, salários injustos; castiga-se como ato violento o roubo de 100 cruzeiros para matar a fome, porque é um ato violento, mas ficam impunes violências muito maiores, como todas as formas de iniqüidade social. É uma violência silenciosa... Ninguém pode responsabilizar ninguém pelas dezenas de milhares de crianças subnutridas, famintas, retardadas, tuberculosas, bestificadas. Mas ninguém ignora que elas também foram vítimas de assaltantes, aqueles que deram um salário de fome a seus pais, que obrigaram suas mães a se prostituírem, que sonegaram impostos, que burlaram a previdência social."

Tais proposições ganharam foro de verdade permanente por meio do conceito de violência estrutural, utilizado até hoje para delimitar melhor o que esse discurso dos anos 70 deixava confuso. A violência estrutural passa a ser distinguida das outras formas de violência: a institucional, a doméstica, a interpessoal (sic). A dificuldade principal desta abordagem é que violência torna-se um sinônimo de desigualdade, exploração, dominação, exclusão, segregação e outros males usualmente associados à pobreza ou a discriminações de cor e de gênero. Não oferece, pois, meios para pensar aquelas ações caracterizadas pelo excesso ou descontrole no uso da força física (ou dos seus inúmeros instrumentos) nas interações sociais, passíveis de controle democrático.

Por isso mesmo, predominantes na literatura de então eram os tropos revolucionários, especialmente claros nos estudos de movimentos messiânicos do início do século, na medida em que as manifestações de violência da população mais destituída eram saudadas como benéficas, mesmo se intraclasse. Um primeiro passo para a grande mudança por vir, uma mudança radical e total, o bem absoluto. Até hoje é possível perceber ecos disto nos trabalhos que denunciam um certo etnocentrismo entre os autores que não reconhecem na violência uma nova forma de sociabilidade dos jovens "pobres" e "marginalizados" (Machado da Silva 1994), de "moradores dos bairros proscritos" (Diógenes, 1998), com seus valores e regras próprios ou suas "éticas particularistas" (Rifiotis, 1997; Soares et alii 1996, passim). Misse (1995b) critica, na mesma tônica, os que não enxergam a associação entre um novo "tipo de criminalidade violenta" e "os modos de operar o poder nas classes subalternas e marginalizadas".
Alguns vão mais longe na recusa de condenar a violência urbana ou tratá-la como um problema a ser enfrentado. Várias correntes da Antropologia que, mais influenciadas pela obra de Foucault, Guattari e Deleuze, sublinham a violência como o fundamento da vida social, ${ }^{11}$ têm marcado autores brasileiros (Diógenes, 1998; Rifiotis, 1997; Rafael, 1998; Soares et alii, 1996). Em seus textos, ou em trechos deles, aparece a idéia defendida abertamente por Rifiotis e Diógenes de que a violência não deve ser vista pelo seu lado negativo ou como "a porta de fundos das teorias sociais", visto que ela teria, no caso da violência entre os jovens, uma positividade (Diógenes, 1998). Somente os compromissos com a "demanda de ordem, o temor da não unidade, a idéia recorrente da totalidade", "o ideal da ordem, da unidade e do equilíbrio", dos quais os cientistas sociais brasileiros seriam signatários, podem explicar a proscrição da violência no "arcaísmo social a ser eliminado", na "ameaça ao consenso". A manifestação pública da violência muda ganharia "positividade" ao "instaurar diferenças", quando "os moradores dos bairros proscritos registram sua existência, tornam públicas as suas redes de exclusão social" (ibidem). Em nome, portanto, da existência e da importância do conflito, da desordem e do dissenso, ${ }^{12}$ compreendem e justificam as manifestações de violência na sociedade brasileira contemporânea, sem ficar claro se incluiriam nessa positividade também os homicídios cometidos pelos jovens entre si ou contra seus vizinhos, até mesmo seus pais.

Cria-se assim uma nova diferença radical dos homens jovens e pobres que pode vir a justificar sua segregação. Nesse caso, não haveria como reconhecer na violência um mal a combater, nem como não estender o conceito de ética particularista a todas as formas de violência existentes no país: a dos policiais militarizados ou corruptos, a dos grupos de extermínio, a dos crimes encomendados por fazendeiros, comerciantes e empresários, a que mata homossexuais, índios, mulheres e crianças. Esta é a principal armadilha do relativismo cultural radical: não há como não admiti-lo para todas as "éticas" ou "etos" existentes, todos "particularistas", inclusive aqueles condenados por serem autoritários, ditatoriais, despóticos ou, ainda, militarizados.

O problema parece estar em associar a violência, mero instrumento usado com maior ou menor intensidade, a um estado social permanente e excessivo na sociedade ou entre os excluídos, explorados ou dominados. Pois a violência sempre foi empregada, no Brasil e no mundo, para forçar o consenso, defender a ordem social a qualquer custo, 
manter a unidade ou a totalidade a ferro e fogo (Capeller, 1995; Costa, 1998; Oliveira, 1994; Soares, G.A., 1993; Soares, D’Araujo e Castro, 1994; Zaverucha, 1994). A questão parece estar, então, não na ausência do conflito, mas na sua forma de manifestação, que possibilita ou não a negociação pela palavra e que envolve diferentes personagens e relações.

Além disso, como assinalaram Paixão e Beato (1997), no Brasil haveria uma ambigüidade na concepção de ordem: a privada, na qual o arbítrio e o emprego de violência nos conflitos recebem ampla aceitação; a pública, na qual a violência empregada torna-se mais visível e é demandada por vários setores da população, desde que não envolva questões de âmbito doméstico. Na primeira, não se negariam os conflitos mas se insistiria na idéia de que são estritamente privados e não devem sofrer a interferência do Estado, tal como no dito popular "roupa suja se lava em casa". Na segunda, os conflitos públicos estariam longe de ser resolvidos pela negociação institucional porque, principalmente entre os menos educados, a experiência negativa com as instituições faria com que a polícia fosse instada a agir de forma violenta. Alternativamente, os próprios populares, em revolta coletiva, fariam a justiça com as próprias mãos e de modo sangrento tal como ocorre nos linchamentos, realizados sem os critérios universais do julgamento "oficial". Do mesmo modo, esses conflitos seriam resolvidos pelas ações fatais dos justiceiros, que recebem amplo apoio popular (Fernandes, 1992).

No prolongado trabalho de campo etnográfico que realizamos com e sem assistentes de pesquisa, essas questões sobre as trapaças do relativismo estiveram permanentemente presentes, dificultando o entendimento. Todavia, a repetição de certos arranjos e associações simbólicas relacionando o uso da arma de fogo, o dinheiro no bolso, a conquista das mulheres, o enfrentamento da morte e a concepção de um indivíduo completamente autônomo e livre adquiriam uma forma que permitia vincular a violência a um etos da masculinidade que, posteriormente consideramos um etos guerreiro, tal como exposto por N. Elias (Zaluar, 1996 e 1998 a e b). Nesse etos, era central a idéia de chefe (Zaluar, 1985, 1988, 1989 e 1994b), ou de um indivíduo absolutamente livre, que se guiava apenas "por sua cabeça". Aqueles arranjos e associações seriam os significados subjetivos, porém compartilhados socialmente, que os entrevistados atribuíam a sua própria ação; este etos, nossa interpretação para algo que não tentamos justificar por ser uma criação de um grupo de "dominados". Haveria recortes de gênero e de geração a considerar para se entender a violência recrudescida. Não se poderia generalizar, portanto, o diagnóstico para toda a sociedade, como afirmamos desde 1983: "Junto a outras crianças e adolescentes morrem numa "guerra" pelo controle do ponto de venda, mas também por quaisquer motivos que ameacem o status ou o orgulho masculino dos jovens em busca de uma virilidade - do "sujeito homem", como afirmam - marcada como resposta violenta ao menor desafio, por conta de rixas infantis, por um simples olhar atravessado, por uma simples desconfiança de traição ou ainda apenas porque estavam lá no momento do tiroteio. Despojado dos hábitos da civilidade que já haviam penetrado o cotidiano das classes populares, um homem, nesse etos, não pode deixar provocações ou ofensas sem respostas, e deve defender sua área, pois a tentativa de invasão pelo inimigo também é interpretada como emasculação.” (Zaluar, 1998a).

"Atraídos por essa identidade masculina, os jovens, nem sempre os mais destituídos, incorporam-se aos grupos criminosos em que ficaram à mercê das rigorosas regras que proíbem a traição e a evasão de quaisquer recursos, por mínimos que sejam. Entre esses jovens, no entanto, são os mais destituídos que portam o estigma de eternos suspeitos, portanto incrimináveis, quando são usuários de drogas, aos olhos discriminatórios das agências de controle institucional. Com um agravante: policiais corruptos agem como grupos de extorsão, que pouca diferença guardam com os grupos de extermínio que se formam com o objetivo de matar os eternos suspeitos. Quadrilhas de traficantes e assaltantes não usam métodos diferentes dos primeiros e tudo leva a crer que a luta pelo butim entre eles estaria levando à morte os seus jovens peões. No esquema de extorsão e nas dívidas com traficantes ou policiais, os jovens que começaram como usuários de drogas são levados a roubar, a assaltar e algumas vezes até a matar para pagar aqueles que os ameaçavam de morte - policiais ou traficantes - caso não consigam saldar a dívida. Muitos deles acabam se tornando membros de quadrilhas, seja para pagar dívidas, seja para se sentirem mais fortes diante dos inimigos criados, afundando cada vez mais nesse círculo diabólico que eles próprios denominam "condomínio do diabo"” (Zaluar, 1988).

Interpretação alternativa para isso é oferecida por Alvito de Souza (1996 e 1998), que usa o conceito de cultura da honra, retirado do seu contexto mediterrâneo, para explicar os conflitos entre jovens nas favelas de Acari no Rio de Janeiro, assim como os embates entre eles e a polícia. Cecchetto (1997 a e b) usa a idéia de etos guer- 
reiro para entender a ambivalência da violência - entre a rixa e o baile, entre a destruição e a sociabilidade - nas galeras funk cariocas. Adorno e Cardia (1997) generalizam o etos da virilidade para todos os homens das classes populares de modo a explicar a solução violenta dos "conflitos intersubjetivos" cada vez mais comuns entre eles na cidade de São Paulo. Na mesma tecla, Diógenes interpreta esse etos como o "retorno do recalcado". Afirma que violência generaliza-se, "deslocaliza-se", "rompe fronteiras", "dessacraliza dualidades", mas são os "novos excluídos" que "rompem as barreiras delimitadoras da cidade da ordem e da cidade da desordem". Para ela, a violência, na sua positividade, serve à diferença: demanda o reconhecimento dela, forma redes de sociabilidade e de micropoderes ou "solidariedades fechadas" que deixam "muitas vezes, atrás de si, marcas de sangue e de lágrimas". Não é um mal, apesar disso. Não exige intervenção.

Essas interpretações ficam, todavia, incompletas quando se considera o contexto nacional e transnacional da cultura globalizada e do crime negócio, também visto de diferentes perspectivas pelos autores mencionados. Isso só ficou claro para nós quando ouvimos a presidente de uma das associações de moradores contar, chorando, em 1988, como as armas de fogo chegavam até o bairro e eram postas nas mãos dos adolescentes pobres, trazidas de carro por desconhecidos. Estes adolescentes, em plena fase de fortalecimento da identidade masculina, aprendiam rápido um novo jogo mortal para afirmá-la, devido à facilidade de obter armas. Havia, então, um fluxo de recursos - armas, drogas e até dinheiro - cuja fonte transcendia a prática fatal dos adolescentes pobres. O escopo da análise teve de ser ampliado até incluir a organização transnacional dos cartéis das drogas e de outras mercadorias negociadas ilegalmente, além, é claro, das instituições locais - a polícia e a Justiça - com as quais esses adolescentes e jovens adultos se mantinham em permanente contato e das quais viviam fugindo (Zaluar, 1993 a, b e c e 1994 a e b). A concepção da violência - no seu excesso e nos seus efeitos maléficos sobre os próprios jovens e seus vizinhos - tornava-se cada vez mais complexa.

Outra inflexão importante ocorreu quando, a partir do final da década de 80 , a posição relativa dos estudos urbanos e rurais sobre a violência e o crime se inverteu. $\mathrm{Na}$ cidade, a falta de clareza nos conflitos, que não seguiam a linhas de classe social, colocou difíceis questões éticas e ideológicas para os que se posicionavam a favor dos dominados contra as instâncias do poder. É que os domi- nados, especialmente os homens jovens e pobres, desenvolviam uma criminalidade violenta na qual eles eram ao mesmo tempo os autores e as vítimas (Zaluar, 1983, 1985, 1988, 1994b). No campo, os cientistas sociais diminuíram o foco na violência entre os dominados, como existiu no cangaço e nos movimentos messiânicos, e ocuparam-se muito mais em denunciar a violência criminosa da classe dominante contra os lavradores e suas lideranças. Nesta, uma transformação foi observada nos últimos 20 anos. Antes, o pistoleiro solitário nada mais era que "o braço armado dos crimes de mando"; hoje, o "bando de homens armados e treinados para atingir lideranças comunitárias" atuaria para expulsar moradores, camponeses ou índios de suas terras ou matá-los. Os objetivos destrutivos e maléficos da violência são claros para tais pesquisadores. Trata-se de desarticular seja as redes de solidariedade e cooperação no trabalho, atingindo e desorganizando unidades familiares (Almeida, 1990), seja os movimentos organizados nas lutas pela posse da terra, atingindo seus líderes (Barreira, 1996 e 1998; Tavares dos Santos et alii, 1999; Adorno, 1995). Neles, a posição crítica dos pesquisadores é clara e não há apelo ao relativismo para "compreender" essa "lógica" fatal em uso pelos dominantes.

Ao longo das décadas, a discussão de diferentes definições de violência trouxe novos elementos e perspectivas para o debate. No número especial da revista Religião e Sociedade, organizado por nós, apresentamos na introdução a discussão sobre as diferenças entre poder e violência, caracterizando esta última como um instrumento e não como um fim. Os instrumentos da violência, segundo Hannah Arendt, seriam mudos, abdicariam do uso da linguagem que caracteriza as relações de poder, baseadas na persuasão, influência ou legitimidade. Outras definições não fogem desse paradigma: a violência como o não reconhecimento do outro, a anulação ou a cisão do outro (Adorno, 1991b e 1995; Cardoso, 1987; Muniz, 1996; Oliveira, 1995; Paixão, 1991; Tavares dos Santos et alii, 1999; Zaluar, 1988, 1989, 1993a e 1994b); a violência como a negação da dignidade humana (Brant, 1989; Caldeira, 1991; Fischer, 1985; Kowarick e Ant, 1981); a violência como a ausência de compaixão (Zaluar, 1994d; Soares et alii, 1996); a violência como a palavra emparedada ou o excesso de poder (Tavares dos Santos et allii, 1999). Em todas elas, ressalta-se, explicitamente ou não, o pouco espaço existente para o aparecimento do sujeito da argumentação, da negociação ou da demanda, enclausurado que fica na exibição da força física pelo seu 
oponente ou esmagado pela arbitrariedade dos poderosos que se negam ao diálogo.

Tavares dos Santos é um dos autores que mais tem refletido sobre a questão teórica da violência, definido como uma forma de sociabilidade "na qual se dá a afirmação de poderes, legitimados por uma determinada norma social, o que the confere a forma de controle social: a violência configura-se como um dispositivo de controle, aberto e contínuo". Mas não seria apenas a manifestação institucional dela, pois a "força, coerção e dano, em relação ao outro, enquanto um ato de excesso, presente nas relações de poder" estaria "seja no nível macro, do Estado, seja no nível micro, entre os grupos sociais". Sua forma social contemporânea estaria expressa no "excesso de poder que impede o reconhecimento do outro - pessoa, classe, gênero ou raça - mediante o uso da força ou da coerção, provocando algum tipo de dano, configurando o oposto das possibilidades da sociedade democrática contemporânea". O problema desta definição parece estar em que não esclarece onde e como o excesso se manifesta, o que implica dizer os limites, regras, normas legitimamente aceitas para o exercício do poder. Isso evidentemente desembocaria no Estado de Direito e na construção da nação. Como, para ele, o direito não é um valor universal, mas sim a dignidade humana, supõe-se que o excesso de poder se balize no que seja indigno, o que reconduz à questão não discutida do limite.

A violência, como qualquer outro instrumento, pode, portanto, ser empregada racional ou irracionalmente, pode ser considerada boa ou má, justificada ou abominada. Uma coisa é certa: a crise institucional, o esgarçamento do tecido social, a difusão recente de práticas violentas em alguns setores da sociedade brasileira fizeram com que os intelectuais brasileiros repetissem o mote da "perda da inocência" e da inequívoca manifestação do lado negro do humano entre nós. Mesmo os que negam a idéia de que estamos fadados à violência, por ser ela o cerne da natureza humana, admitem que a igualdade não seria algo inerente ao espírito humano ou enraizado na sociedade brasileira; tampouco seria conseqüência inevitável do crescimento econômico e de qualquer "modernidade". A idéia recorrente é a de que nem a democracia, nem a igualdade, nem a inclinação para a paz seriam inerentes à natureza humana ou à índole do brasileiro. Em outras palavras, o movimento nessa direção, caso parte de um projeto político almejado, dependeria de um processo de educação permanente para as novas formas de viver, de prestar contas, de construir formas democráticas e participativas de controle, de exigir a segurança como um bem coletivo ou público. Todavia, os espectros do desalento, do cinismo e da indiferença já haviam começado a nos rondar.

\section{NOTAS}

Este artigo é a parte inicial de um texto de 54 laudas escrito para o livro em preparação pela Anpocs a respeito dos 25 anos de Ciências Sociais no Brasil, organizado por Sérgio Micelli. É como se fosse uma introdução ao debate que tentamos organizar posteriormente, tematizando o campo de discussões e explicitando as idéias dos autores que dele participaram. Dos temas abordados, detemonos apenas no primeiro: o que é violência.

1. O acesso ao Urbandata, dirigido por Lícia Valladares, foi possível graças ao prestimoso atendimento de seus funcionários e à cooperação existente entre este arquivo e o Curso de Especialização em Sociologia Urbana da Uerj. O levantamento foi feito por Paulo Jorge da Silva Ribeiro e Luís Fernando de Almeida Pereira, alunos do PPCIS/Uerj, a quem agradecemos pela eficiência e pelo cuidado.

2. É claro que não são as idéias do liberalismo econômico acerca da importância primordial do mercado para o equilíbrio da sociedade que inspiraram esses autores. Foram as teses do liberalismo político, baseadas na separação entre o poder religioso e o político, assim como na rejeição à interferência da autoridade política nas crenças, opiniões e ações dos indivíduos no exercício de suas liberdades negativas e positivas, assim como de seus deveres para com os outros indivíduos e para com a nação assim constituída.

3. A postura relativista levada às últimas conseqüências, como se sabe, pressupõe universos culturais discretos e fechados, bem como a diferença radical incomunicável.

4. Num certo sentido, tais concepções apresentaram uma continuidade, apesar do seu apelo ao multiculturalismo e ao relativismo cultural, com a visão ortodoxa de uma sociedade dividida em dois: os dominantes e os dominados.

5. Nessa contagem, utilizamos principalmente os textos encontrados no Urbandata, nem todos na bibliografia.

6. É interessante notar que Foucault concebia o poder exercido sobre o corpo, sem um locus ou instância específica, para discipliná-lo ou domesticá-lo. Essa concepção contesta, mesmo que sem explicitá-lo, os limites impostos ao uso da força física, isto é, da capacidade violenta do corpo. Mas o mesmo Foucault, quando analisa erros judiciários, enfatiza que o poder silencia as pessoas.

7. No antigo Estado da Guanabara, uma pesquisa, patrocinada e publicada em 1973 pelo Tribunal de Justiça e pelo Juizado de Menores reuniu vários sociólogos e discutiu os primeiros dados sobre a delinquiência juvenil no Estado (apud Misse, 1995b). Em São Paulo, Maria Célia Paoli realiza pesquisa no final dos anos 70 com seus alunos na USP, mas sem divulgá-la. Em Minas Gerais, Antônio Luís Paixão discute teorias da criminologia americana com base em séries históricas da criminalidade naquele Estado. No Rio de Janeiro, Edmundo Campos Coelho inicia uma série de estudos que discutia a associação entre pobreza e o aumento da criminalidade observada no final da década de 70. Outros trabalhos, de menor visibilidade, foram listados por Misse (1995b:86), atestando a pouca importância do tema no cenário nacional e o papel pioneiro de tais estudos.

8. Participaram deste grupo alguns veteranos sociólogos, tais como Pe. Fernando Bastos D'Avila e José Artur Rios.

9. A Constituição regulamentou dois aspectos da noção de cidadania: a garantia aos direitos e liberdades individuais em face dos excessos do poder do Estado e dos predadores criminosos, mas o primeiro ocupou a quase totalidade das preocupações de tais autores.

10. O único a tratar de linchamentos realizados no campo é Almeida (1997) que acentua, porém, o seu caráter episódico e contingencial, e afirma que não chega a constituir um sistema de justiça alternativo ou paralelo entre os camponeses. Como algo novo, o linchamento seria derivado da combinação entre valores tradicionais de justiça e novos modos de organização coletiva entre camponeses na sua luta contra a ordem oligárquica.

11. Dumezil e Mircea Eliade apresentam como a razão do enigma do mal a própria ambivalência do sagrado, a um só tempo negativo e positivo, montado na violência e no simbolismo. Bataille, sob a influência do surrealismo, critica a teoria da reciprocidade de Mauss e afirma a negatividade do dom no próprio desgaste dos bens no consumo, marcado pela destruição e pelo excesso. René Girard afirma que o sagrado não é a sociedade, mas a própria violência: a vítima sacrificial, ou seja, a vítima inocente escolhida, não por seus supostos crimes 
mas porque tem sinais próprios do monstruoso, passa a incorporar todo o mal que atinge a coletividade. Esta descarregaria naquela a sua violência sagrada, evitando a cadeia de vinganças privadas. Tais teorias têm recebido severas críticas. Primeiro porque pressupõem uma situação persecutória e paranóica para caracterizar o social, utilizando-se de um pensamento circular e tautológico para explicar a violência neles contida. Segundo porque qualquer pessoa pode ser colocado na posição de vítimas contagiadas e contagiantes quando o mal é cósmico, o que não se aplica aos crimes individuais efetivamente cometidos contra outrem e que têm, em qualquer sociedade, meios próprios de reestabelecer a paz e a justiça. Ela é, no entanto, muito eficaz para explicar fenômenos em que coletividades ou comunidades se unem para dela extirpar estranhos que supostamente ameaçam a sua ordem interna: linchamentos físicos e morais, genocídios, terrorismo, extermínios ou limpezas étnicas. Seu caráter sagrado advém daí e o seu horror do fato de que a vítima sacrificial é quase sempre inocente. Esta simbólica cósmica, no plano religioso, teria sido superada com o martírio do próprio Cristo que sofreu e morreu por toda a Humanidade, numa tentativa de apaziguála. No plano político, pela invenção do Estado e suas instituições de pena e castigo em nome de toda a sociedade, superando a vingança pessoal e de pequenos grupos. Nenhuma destas alternativas à violência sagrada foi completamente exitosa, no entanto, continuando a vigorar a vingança coletiva carregada de emoção ou pathos contra pessoas que exibem marcas do diferente.

12. Lendo cuidadosamente tais textos e suas referências foi possível reconhecer a importância que um trabalho de Wanderley Guilherme dos Santos teve nessa produção do sentido da violência entre os cientistas sociais

\section{REFERÊNCIAS BIBLIOGRÁFICAS}

ADORNO de ABREU, S.F. Violência urbana, justiça criminal e organização social do crime. São Paulo, Núcleo de Estudos da Violência - USP, 1990, mimeo.

"A prisão sob a ótica de seus protagonistas". Tempo Social. São Paulo, v.3, n.1-2, 1991a.

"Sistema penitenciário no Brasil". Revista USP. São Paulo, n.9, 1991b.

"Violência criminal na moderna sociedade brasileira: o caso do Estado de São Paulo". Congresso Polícia Militar, Estado e Sociedade. Belo Horizonte, 1992

."A criminalidade urbana violenta no Brasil: um recorte temático". BIB. Rio de Janeiro, n.35, 1ำ sem. 1993.

"A violência na sociedade brasileira: um painel inconcluso em uma democracia não consolidada”. Sociedade e Estado. Brasília, v.10, n.2, jul./dez., 1995, p.299-342.

ADORNO, S. e CARDIA, N. "Dilemas do controle democrático da violência: execuções primárias e grupos de extermínio em São Paulo". São Paulo, Núcleo de Estudos da Violência - USP, 1997, mimeo.

ALMEIDA, A.W.B. de. Terra, conflito e cidadania: relato das violências cometidas contra índios e camponeses na região amazônica. Apresentado na sessão sobre Amazônia Brasileira no Tribunal Permanente dos Povos. Paris, 1990, mimeo.

ALVITO DE SOUZA, M. “A honra de Acari”. In: VELHO, G. e ALVITO, M. Cidadania e Violência. Rio de Janeiro, Ed. da UFRJ, 1996.

. As cores de Acari. Tese de Doutorado. São Paulo, USP, 1998.

BARREIRA, C. "Os pactos na cena política cearense". Revista do Instituto de Estudos Brasileiros. São Paulo, n.40, 1996.

. Crimes por encomenda. Rio de Janeiro, Ed. Relume Dumará, 1998.

BEATO FILHO, C.; ASSUNÇÃO, R. e SANTOS, M.C. "Análise da evolução temporal da criminalidade violenta em Minas Gerais" (1986-1997). São Paulo, 1997, mimeo.

BENEVIDES, M.V. "A violência através da imprensa: os linchamentos e a justiça popular”. Espaço \& Debates. São Paulo, ano 1, n.3, 1981.

"Linchamentos: violência e justiça popular". A Violência Brasileira. São Paulo, Brasiliense, 1982.

. Violência, povo e polícia (violência urbana no noticiário da imprensa). São Paulo, Brasiliense/Cedec, 1983.

"A violência policial pode conviver com a democracia?". Lua Nova. São Paulo, v.1, n.4, 1985.
BRANT, V.C. São Paulo: trabalhar e viver. São Paulo, Brasiliense, 1989.

BRETAS, M.L.: "Observações sobre a falência dos modelos policiais". Tempo Social. Revista de Sociologia da USP. São Paulo, v.9, n.1, 1997.

CALDEIRA, C. "Operação Rio e Cidadania: as tensões entre o combate à criminalidade e a ordem judiciária". XIX Encontro Anual da Anpocs, Caxambu, publicado In: REIS, E., ALMEIDA, M.H.T. \& FRY, Política e Cultura: visões do passado e perspectivas contemporâneas. São Paulo, Hucitec/ Anpocs, 1995.

"Segurança pública e seqüestros no Rio de Janeiro: 1995/ 96". Revista Brasileira de Ciências Criminais. Rio de Janeiro, n.20, out./dez. 1997.

CALDEIRA, T.P. "Direitos humanos ou 'privilégios de bandidos'?”. Novos Estudos Cebrap. São Paulo, n.30, 1991.

City of walls. Tese de Doutorado. Berkeley, 1992.

CAMPOS COELHO, E. "A criminalização da marginalidade e a marginalização da criminalidade". Revista Brasileira de Administração Pública. Rio de Janeiro, FGV, 12 (2), 1978a.

A ecologia do crime na Guanabara. Rio de Janeiro, Comissão de Justiça e Paz/Educam, 1978b.

"Sobre sociólogos, pobreza e crime". Dados: Revista de Ciências Sociais. Rio de Janeiro, v.23, n.3, 1980

"A criminalidade urbana violenta". Série Estudos. Rio de Janeiro, Iuperj, 1987a

A oficina do diabo. Rio de Janeiro, Iuperj/ Espaço e Tempo, 1987b.

"Da Falange Vermelha a Escadinha: o poder nas prisões". Presença. Rio de Janeiro, n.11,1988.

CAPELLER, W. de L. L'engrenage de la répression. Droit et Societé, Paris, L.G.D.J., v.13, 1995.

CARDIA, N. "A violência urbana e a escola". Contemporaneidade e Educação. Rio de Janeiro, n.2, set. 1997.

CARDOSO, R.C.L. "A violência dos outros". Ciência Hoje. Rio de Janeiro, v.5, n.28, jan./fev. 1987

CARRARA, S. "O crime de um certo custódio e o surgimento do manicômio judiciário no Brasil". Dados. Revista de Ciências Sociais. Rio de Janeiro, v.34, n.2, 1991a.

"Singularidade, igualdade e transcendência: um ensaio sobre o significado social do crime". Revista Brasileira de Ciências Sociais. São Paulo, v.6, n.16, jul. 1991b.

CARVALHO, M.A.R. de. "Contra o 'espantalho da repressão': a polícia e a construção da ordem burguesa no Brasil”. Revista $O A B / R J$ - A instituição policial. Rio de Janeiro, n.22, jul. 1985

Quatro vezes cidade. Rio de Janeiro, Sette Letras, 1994

"Cidade escassa e violência urbana". Série Estudos. Rio de Janeiro, n.91, 1995

CAVALCANTE, B. "A polícia e a nação: a necessidade de "segurança interna e tranqüilidade pública". Revista OAB/RJ - A instituição policial. Rio de Janeiro, n.22, jul. 1985 .

CECCHETTO, F. Galeras funk cariocas: o baile e a rixa. Tese de Mestrado. Rio de Janeiro, PPCIS-Uerj, 1997a.

"Galeras funk cariocas: entre o lúdico e o violento". In: VIANNA, H. Galeras Cariocas, Rio de Janeiro, Editora da UFRJ, 1997b.

CDDHBR - CENTRO DE DEFESA DOS DIREITOS HUMANOS BENTO RUBIÃO . Favelas e as organizações comunitárias. Petrópolis, Vozes, 1994.

CHINELLI, F. e MACHADO DA SILVA, L.A. "O vazio da ordem: relações políticas e organizacionais entre o jogo do bicho e as escolas de samba". Revista do Rio de Janeiro - Uerj. Rio de Janeiro, Universidade Estadual do Rio de Janeiro \& Ayuri Editorial, 1993.

COELHO, M.P. "Crime organizado e pobreza: uma nova associação". In: Polícia Militar, Estado e Sociedade: os desafios da modernidade. Belo Horizonte, Fundação João Pinheiro, 1992.

COSTA, M.R. da. "A constituição do esquadrão da morte". XXII Encontro Anual da Anpocs. Anais... Caxambu, 1998.

CPDOC-FGV/ISER. Lei, justiça e cidadania: direitos, vitimização e cultura política na Região Metropolitana do Rio de Janeiro. Sinopse dos resultados da pesquisa CPDOC-FGV/Iser. Rio de Janeiro, 1997a. 
Lei, justiça e cidadania: cor, religião, acesso à informação e serviços públicos. Sinopse dos resultados da pesquisa CPDOC-FGV/Iser. Rio de Janeiro, 1997b.

CUNHA, O.M.G. da. "Cinco vezes favela uma reflexão". In: VELHO, G. e ALVITO, M. (orgs.). Cidadania e Violência, Rio de Janeiro, Editora da UFRJ/Editora da FGV, 1996.

DIÓGENES, G.M. Cartografias da cultura e da violência, gangues, galeras e o movimento hip hop. São Paulo, AnnaBlume Ed./Governo do Estado do Ceará, 1998.

FERNANDES, H.R. "Violência e modos de vida: os justiceiros. Tempo Social. São Paulo, v.4, n.1/2, 1992.

FERNANDES, R.C. e CARNEIRO, L.P. "Criminalidade, drogas e perdas econômicas no Rio de Janeiro". Lei e liberdade, Rio de Janeiro, ano 15, n.47, 1996.

FISCHER, R.M. O direito da população à segurança: cidadania e violência urbana. Petrópolis, Vozes/Cedec, São Paulo, 1985.

GOLDMAN, S.N. O crime organizado nas prisões: sua trajetória e o seu rebatimento no Serviço Social do Desipe. Rio de Janeiro, Escola de Serviço Social/UFRJ, 1990.

GREGORI, M.F. Meninos nas ruas: a experiência da viração. Tese de Doutorado. São Paulo, USP, 1997.

GUIMARÃES, A.P. As classes perigosas. Rio de Janeiro, Graal, 1982.

KANT DE LIMA, R. "A cultura jurídica e as práticas policiais". Revista Brasileira de Ciências Sociais, n.10, v.4, 1989.

"Tradição inquisitorial no Brasil, da colônia à República". Religião e Sociedade. Rio de Janeiro, Iser, 1992.

. A polícia da cidade do Rio de Janeiro: seus dilemas e paradoxos. Rio de Janeiro, Forense, 1995.

"Polícia e exclusão na cultura judiciária". Tempo Social. São Paulo, v.9, n.1, 1997.

KOVARICK, L. e ANT, C. Violência: reflexões sobre a banalidade do cotidiano em São Paulo". In: BOSCHI, R. Violência e Cidade. Rio de Janeiro, Zahar Ed., 1981.

MACHADO DA SILVA, L.A. "Violência e sociabilidade: tendências da atual conjuntura urbana no Brasil". In: QUEIROZ RIBEIRO, L.C. e SANTOS Jr, O.A. (orgs.) Globalização, fragmentação e reforma urbana. Rio de Janeiro, Ed. Civilização Brasileira, 1994.

MACHADO, E. e TAPPARELI, G. "Violência juvenil, inflação e morte nas quadrilhas de Salvador". Cadernos do SEAS. Salvador, n.165, set./ out. 1993.

MARQUES JUNIOR, G. A vida no Fio: crime e criminalidade num albergue de Campinas. Tese de Mestrado. Campinas, Unicamp, 1991.

MINAYO, M.C. de S. "A violência na adolescência: em foco a adolescência 'descamisada”". Cadernos de Saúde Pública, v.6, n.3, jul./set. 1990.

MINGARDI, G. Tiras, gansos e trutas, cotidiano e reforma da polícia civil. São Paulo, Scritta Editorial, 1992.

. "Crime organizado: tipo ideal e variação local - o caso paulista". GT18, XXI Congresso da ALAS. São Paulo, 1997, mimeo.

"O que é crime organizado: uma definição das ciências sociais". Revista do Ilanud, n.8. São Paulo, Ilanud, 1998.

MISSE, M. "Cinco teses equivocadas sobre a criminalidade urbana no Brasil: uma abordagem crítica, acompanhada de sugestões para uma agenda de pesquisas". Série Estudos, n.91. Rio de Janeiro, 1995a.

. "Crime e pobreza: velhos enfoques, novos problemas". In: VILLAS BOAS, G. e GONÇALVES, M.A. (orgs.). O Brasil na virada do século. Rio de Janeiro, Ed. Relume Dumará, 1995b.

"As ligações perigosas: mercado informal ilegal, narcotráfico e violência no Rio". Contemporaneidade e educação. Rio de Janeiro, ano 2 , n.1, maio 1997.

MISSE, M. e MOTTA, D. Crime: o social pela culatra. Rio de Janeiro, AchiaméSocii, 1979.

MOTA, P.P. A Polícia e os pobres: representações sociais e práticas em delegacias de polícia do Rio de Janeiro e o serviço social. Tese de Mestrado Escola de Serviço Social/UFRJ, Rio de Janeiro, 1995.

MUNIZ, J. "Os direitos dos outros e outros direitos: um estudo sobre a negociação de conflitos nas DEAMs/RJ". In: SOARES, L.E. et alii. Violência e política no Rio de Janeiro. Rio de Janeiro, Relume Dumará/ ISER, 1996.
MUNIZ, J.; LARVIE, S.P.; MUSUMECI, L. e FREIRE, B. "Resistências e dificuldades de um programa de policiamento comunitário". Tempo Social. São Paulo, v.9, n.1, maio 1997.

MUNIZ, J.; LARVIE, S. P.; MUSUMECI, L. "Imagem da desordem e modelo de policiamento". Comunicações do Iser, cidade em movimento. Rio de Janeiro, Iser, n.49, ano 17, 1998.

OLIVEIRA, L. Do nunca mais ao eterno retorno: uma reflexão sobre a tortura no Brasil. São Paulo, Brasiliense, 1994.

Imagens da democracia: os direitos humanos e o pensamento político de esquerda no Brasil. Recife, Pindorama Editora, 1995.

OLIVEN, R.G. "A violência como mecanismo de dominação e como estratégia de sobrevivência". Dados. Rio de Janeiro, v.23, n.3, 1980.

"Chame o ladrão: as vítimas da violência no Brasil". In: BOSCHI, R. Violência e cidade. Rio de Janeiro, Zahar Ed., 1981.

Violência e cultura no Brasil. Rio de Janeiro, Editora Vozes, 1982.

PAIXÃO, A.L. "A organização policial numa área metropolitana". Dados. Rio de Janeiro, v.25, n.1, 1982.

"Crimes e criminosos em Belo Horizonte: 1932-1978". In: PINHEIRO, P.S. (org.) Crime, violência e poder. São Paulo, Brasiliense, 1983. "Crime, controle social e consolidação da cidadania", In: REIS, F. W. e O'DONNELL, G. A democracia no Brasil: dilemas e perspectivas. São Paulo, Vértice, 1988.

"A violência urbana e a sociedade: sobre crenças e fatos, mitos e teorias". Religião e sociedade. Rio de Janeiro, v.15, n.1, 1990.

"Segurança privada, direitos humanos e democracia". Novos Estudos. São Paulo, Cebrap, n.31, 1991

. "O problema da polícia”. Série estudos, n.91. Rio de Janeiro, 1995.

PAIXÃO, A.L. e BEATO FILHO, C.C. "Crimes, vítimas e policiais”. Tempo Social. São Paulo, v.9, n.1, maio 1997.

PAOLI, M.C. "Violência e espaço civil". In: A violência brasileira. São Paulo, Brasiliense, 1982

PINHEIRO, P.S. "Polícia e crise política: o caso das polícias militares". In: A violência brasileira. São Paulo, Brasiliense, 1982.

Escritos indignados. São Paulo, Brasiliense, 1984.

RAFAEL, A. Um abraço para todos os amigos. Niterói, Eduff, 1998.

RAMALHO, J.R. Mundo do crime, a ordem pelo avesso. $1^{\text {a }}$ ed. (2a ed. 1983). Rio de Janeiro, Ed. Graal, 1979.

RIFIOTIS, T. Nos campos da violência: diferença e positividade. Florianópolis, 1997, mimeo.

SHIRLEY, R.W. "Atitudes com relação à polícia em uma favela do sul do Brasil”. Tempo Social. São Paulo, v.9, n.1, maio 1997.

SOARES, G.A.D. "A violência na América Latina". Revista Brasileira de Ciências Sociais. Rio de Janeiro, n.21, ano 8, 1993.

SOARES, G.A.D.; D'ARAUJO, M.C.S. e CASTRO, C. A repressão. Rio de Janeiro, Ed. Relume Dumará, 1994.

SOARES, L.E.; SANTO-SÉ, J.T.; RODRIGUES, J., A.S. e PIQUET CARNEIRO, L. Violência e política no Rio de Janeiro. Rio de Janeiro, Ed. Relume Dumará, 1996.

SOUZA, E.R. de. "Violência velada e revelada: estudo epidemiológico da mortalidade por causas externas em Duque de Caxias, Rio de Janeiro". Cadernos de Saúde Pública. Rio de Janeiro, v.9, n.1, jan./mar. 1993.

SOUZA, M. J.L. de. "O tráfico de drogas no Rio de Janeiro e seus efeitos negativos sobre o desenvolvimento sócio-espacial". Cadernos/UFRJ. Rio de Janeiro, ano 8, n.2/3, set./dez. 1994.

“As drogas e a 'questão urbana' no Brasil: a dinâmica sócio-espacial nas cidades brasileiras sob influência do tráfico de tóxicos”. In: CASTRO, I.E de; GOMES, P.C. da C. e CORRÊA, R.L. (orgs.). Brasil: questões atuais da reorganização do território. Rio de Janeiro, Bertrand Brasil Ed., 1996.

SUSSEKIND, E. "A manipulação política da criminalidade". Ciência Hoje. Rio de Janeiro, v.5, n.28, jan./fev. 1987.

TAVARES DOS SANTOS, J.V.; DIDONET, B. e SIMON, C. "A palavra e o gesto emparedados: a violência na escola". XXII Encontro Anual da Anpocs, Caxambu. Publicado em Violência Não Está Com Nada. Secretaria Municipal de Educação de Porto Alegre (org.). Porto Alegre, abril 1999. 
VARGAS, J.D. Fluxo do sistema de justiça criminal para crimes sexuais, a organização policial. Tese de Mestrado. Campinas, Unicamp, 1997.

VARGAS, J.H. À espera do passado: as transformações recentes de São Paulo vistas de seu epicentro. Tese de Mestrado. Campinas, Unicamp, 1993.

VELHO, G. "Violência e cidadania". Dados. Rio de Janeiro, v.23, n.3, 1980.

. "O Cotidiano da violência: identidade e sobrevivência", Boletim do Museu Nacional. Rio de Janeiro, n.56, abr. 1987.

."Violência, reciprocidade e desigualdade: uma perspectiva antropológica". In: VELHO, G. e ALVITO, M. (orgs.). Cidadania e violência. Rio de Janeiro, Editoras UFRJ/FGV, 1996.

ZALUAR, A. "Condomínio do diabo: as classes populares urbanas e a lógica do ferro e do fumo", Simpósio, IFCH, UNICAMP, mimeo, (1982). In: PINHEIRO, P.S. (org.) Crime, violência e poder. Brasiliense, São Paulo, 1983 . A Máquina e a revolta. 1ª ed. São Paulo, Brasiliense, 1985.

"O Rio contra o crime". Revista Presença, n.5, 1985a.

"Crime e trabalho: o cotidiano das classes populares". Revista Ciência Hoje, jul., 1986b.

. "Teleguiados e chefes". Religião e Sociedade, n.14/1, 1988.

. "Nem líderes nem heróis". Revista Presença, n.13, 1989.

"Gênero, justiça e violência". Revista Dados. Rio de Janeiro, Iuperj, v.34, n.12, 1991a.

"Brasil na transição: cidadãos não vão ao paraíso". São Paulo em Perspectiva. São Paulo, Fundação Seade, v.5, n.1, p. 19-25, jan./mar. 1991 b.
Cidadãos não vão ao paraíso. Tese de Livre-Docência. Campinas, Ed. da Unicamp e Escuta, 1991c.

"A criminalização de drogas e o reencantamento do mal". Revista do Rio de Janeiro - Uerj, v. I, fasc. 1, 1993a.

. "Mulher de bandido: crônica de uma cidade menos musical". Estudos Feministas, v.1, fasc. 1, p. 135-142, 1993 b.

. "Relativismo cultural na cidade?". Anuário Antropológico 90. Rio de Janeiro, Ed. UNB/Tempo Brasileiro, 1993c.

"Violência, crime organizado e poder: a tragédia brasileira e seus desafios". In: VELLOSO, J.P. (org.). Governabilidade, sistema político e violência urbana. Rio de Janeiro, José Olympio, 1994a.

. Condomínio do diabo. Rio de Janeiro, Ed. da UFRJ e Revan, 1994b.

. "Crime, medo e política". Sociedade e estado. Brasília, Editora UNB, v.X, n.2, jul./dez. 1995.

"A globalização do crime e os limites da explicação local". In: VELHO, G. (org.). Cidadania e violência. Rio de Janeiro, Ed. da UFRJ, 1996.

"Para não dizer que não falei de samba, os enigmas da violência no Brasil". In: SCHWARTZ, L. (org.). História da vida privada. São Paulo, Cia. das Letras, v. IV, 1998a.

Cem anos de favela (co-org. com Marcos Alvito). Rio de Janeiro, Ed. da FGV, 1998b.

ZAVERUCHA, J. Rumor de sabres. São Paulo, Ed. Ática, 1994. 